\title{
PENGAMATAN PERTUMBUHAN TANAMAN BAYAM (Amaranthus tricolor L.) PASCA APLIKASI BIOFERTILIZER (BAHAN AKTIF Aspergillus sp.) SEDIAAN CAIR
}

\section{Observation Of Spinach (Amaranthus tricolor L.) Growth After The Addition Of Liquid Biofertilizer (Active Ingredient Aspergillus sp.)}

\author{
Yulia Astutui ${ }^{1}$, Umrah $^{1^{*}}$ dan Abdul Rahim Thaha ${ }^{2}$ \\ 1'Jurusan Biologi Fakultas Matematika dan IImu Pengetahuan Alam Universitas Tadulako Tondo Palu, \\ Sulawesi Tengah 94118 \\ ${ }^{2}$ Jurusan Agroteknologi Fakultas Pertanian Universitas Tadulako Tondo Palu, Sulawesi Tengah 94118
}

Keywords:

Biofertilizer,

Aspergillus sp,

Fermented

Soybean Liquid

Waste, Coconut

Water
Kata Kunci: Biofertilizer, Aspergillus sp, Limbah cair tempe, Air kelapa

\section{ABSTRACT}

The study about the observation of spinach (Amaranthus tricolor L.) growth after the addition of liquid biofertilizer (active ingredient Aspergillussp.) had been conducted in Taman Pangan Gizi Langaleso Village, Dolo Subdistrict, Sigi District, Central Sulawesi, and Laboratory of Biotechnology, Biology Department, Faculty of Mathematics and Natural Sciences, Tadulako University, Palu, from March to November 2018. The aim of the study was to observe the growth of spinach after the addition liquid biofertilizer (active ingredient Aspergillus sp.) along with the fermented soybean liquid waste and coconut water waste as the main media. This study was designed using the Completely Randomized Design which consisted of 7 treatments with 5 repetitions. The treatments were arranged as follows: P0 (without the addition ofbiofertilizer, as the negative control), P1 (2.5\%biofertilizer addition), P2 (5\%biofertilizer addition), P3 (7.5\%biofertilizer addition), P4 (10\%biofertilizer addition), P5 (12.5\%biofertilizer addition), P6 (NPK addition, without the addition of biofertilizer, acting as the positive control). The results showed that treatment P4 was indicated as the best growth among any other treatments as well as the control, based on the parameters of the height of the plants $(10 \mathrm{~cm})$, the number of leaves (8.35 leaf blades), the dry weight of biomass $(1.95 \mathrm{~g})$, the fresh weight of canopy (4.94), the fresh weight of leaves $(2.07 \mathrm{~g})$, the dry weight of leaves $(0.22 \mathrm{~g})$, the fresh weight of roots $(2.11 \mathrm{~g})$, the dry weight of roots $(0.24$ $\mathrm{g}$ ) and the length of the roots $(12.2 \mathrm{~cm})$.

\section{ABSTRAK}

Penelitian tentang pengamatan pertumbuhan tanaman bayam (Amaranthus tricolor L.) pasca aplikasi biofertilizer (bahan Aktif Aspergillus sp.) sediaan cair telah di laksanakan Di Taman Pangan Gizi Desa Langaleso, Kecamatan Dolo, Kabupaten Sigi, Sulawesi Tengah dan Laboratorium Bioteknologi Jurusan Biologi Fakultas Matematika dan IImu Pengetahuan Alam Universitas Tadulako Palu, pada bulan Maret sampai November 2018. Tujuan penelitian ini adalah untuk mengamati pertumbuhan tanaman bayam pasca aplikasi biofertilizer (bahan Aktif Aspergillus sp.) sediaan cair, dengan medium pembawa limbah cair tempe dan limbah air kelapa. Penelitian ini didesain dalam Rancangan Acak Lengkap (RAL) terdiri dari tujuh perlakuan dan lima kali ulangan, Susunan perlakuan sebagai berikut; P0 (tanpa aplikasi biofertilizer, sebagai kontrol negatif), P1(aplikasi biofertilzer 2,5\%), P2 (aplikasi biofertilzer 5\%), P3 (aplikasi biofertilzer 7,5\%), P4 (aplikasi biofertilzer 10\%), P5 (aplikasi biofertilzer 12,5\%), P6 (aplikasi NPK, tanpa aplikasi biofertilizer sebagai kontrol positif). Hasil pengamatan menunjukkan perlakuan P4 terlihat pertumbuhan yang terbaik dibandingkan perlakuan yang lain dan kontrol, berdasarkan parameter rata-rata tinggi tanaman $(10 \mathrm{~cm})$, jumlah daun $(8,35$ helaian), berat kering biomassa $(1,95 \mathrm{~g})$, berat segar tajuk $(4,94 \mathrm{~g})$, berat segar daun $(2,07 \mathrm{~g})$, berat kering daun $(0,22 \mathrm{~g})$, berat segar akar $(2,11 \mathrm{~g})$, berat kering akar $(0,24 \mathrm{~g})$ dan panjang akar $(12,2 \mathrm{~cm})$.

Corresponding Author : umrah.mangonrang62@gmail.com 


\section{PENDAHULUAN}

Tanaman bayam (Amaranthus tricolor L.) merupakan tanaman sayuran yangbanyak digemari oleh kalangan masyarakat karena memiliki gizi yang tinggi meliputi kandungan kalsium dan vitamin A. Bayam termasuk sayuran yang dapat hidup baik pada dataran tinggi, maupun di dataran rendah. Di Indonesia dikenal dua jenis bayam yang banyak di budidaya, yaitu $A$. tricolor dan $A$. hybridus. Pertumbuhan vegetatif (batang dan daun) tanaman bayam membutuhkan nitrogen lebih tinggi. Nitrogen di dalam tanah tidak selalu dapat mencukupi kebutuhan bayam, sehingga untuk mengatasi kekurangan tersebut perlu dibantu dengan penggunaan pupuk (Amir dkk., 2012).

Tingginya penggunaan pupuk menyebabkan perubahan dalam sistem pertanian untuk mendapatkan hasil yang maksimal bagi tanaman (Kuhn, 2007). Penerapan system pertanian saat ini, cenderung masih menggunakan pupuk anorganik atau pupuk kimiawi untuk memenuhi kebutuhan nitrogen pada tanaman. Penggunaan pupuk anorganik dalam jumlah yang cukup banyak dapat menyebabkan pencemaran lingkungan dan degrades tanah. Pupuk anorganik jika digunakan dalam jangka waktu yang lama dapat menghasilkan residu (Biswas,1985). Alternatif yang dapat ditempuh oleh petani untuk mengatasi dampak dari penggunaan pupuk kimiawi sekaligus mengatasi masalah ketersediaan nitrogen bagi tanaman adalah dengan menggunakan bioferlizer. Penggunaan biofertilizer lebih ramah lingkungan sebab tidak merusak struktur akar maupun tanah (Amir dkk., 2012).

Biofertilizer mulai banyak digunakan, karena memiliki berbagai macam kelebihan di banding pupuk organik padat. Biofertilizer lebih mudah tersedia, tidak merusak tanah dan tanaman, dan mempunyai larutan pengikat sehingga jika diaplikasikan dapat langsung digunakan oleh tanaman, dapat diberikan melalui akar maupun daun sehingga mudah diserap karena unsur haranya telah terurai (Duaja, 2012). Kualitas hasil biofertilizer pada prinsipnya ditentukan oleh bahan baku, proses pembuatan, produk akhir, pengemasan dan mikroorganisme pengurai.

Jamur saprofit yang banyak terdapat di alam salah satunya yaitu Aspergillus sp. Di daerah tropik, dengan kelembaban yang tinggi jamur tersebut mampu hidup di semua bahan yang ditumbuhi oleh jamur (Jawetz dkk., 1996). Spesies dari genus Aspergillus sp. terdistribusi secara luas diseluruh dunia dan memiliki kapasitas berkembang diberbagai macam substrat. Aspergillus sp. banyak digunakan dalam industri fermentasi untuk menghasilkan asam organik serta enzim amilase (Silva et al., 2011). 
Ciri khas dari Aspergillus sp. memiliki benang-benang tunggal yang disebut hifa atau berupa kumpulan benang-benang padat menjadi satu dan bersifat aerobik (Smith dan Patteman, 1977), namun ada beberapa spesies Aspergillus sp. yang sulit untuk diidentifikasi (Varga et al., 2019). Aspergillus sp. berperan penting dalam dekomposisi, bioremediasi dan sebagai biokontrol. Spesies Aspergillus sp. digunakan untuk menghasilkan asam organik, enzim dan metabolit sekunder (Kagot e al., 2019).

Limbah cair tempe dapat dimanfaatkan sebagai biofertilizer. Limbah cair tempe memiliki kandungan yang dapat dimanfaatkan sebagai pupuk organik oleh

\section{BAHAN DAN METODE}

Alat-alat yang digunakan pada penelitian ini yaitu alat tulis menulis, $\mathrm{pH}$ meter, kamera, wadah, aerator, selang aerator, gelas ukur $100 \mathrm{ml}$, autoclave, mistar, timbangan, neraca analitik, oven, pollybag ukuran $25 \times 30 \mathrm{~cm}$, saringan dan erlenmeyer.

\section{Rancangan Penelitian}

Penelitian ini didesain dalam Rancangan acak lengkap (RAL), yang terdiri dari tujuh perlakuan dan lima kali ulangan. Susunan perlakuan sebagai berikut; PO (tanpa aplikasi biofertilizer, sebagai kontrol negatif), P1(aplikasi biofertilzer 2,5\%), P2 (aplikasi biofertilzer 5\%), P3 (aplikasi biofertilzer 7,5\%), P4 (aplikasi biofertilzer para petani untuk mengoptimalkan produksi jagung. Hasil analisis menunjukkan limbah cair tempe mengandung Karbon sebesar $7,1 \%$ dan kandungan Nitrogen sebesar $3,3 \%$ yang dapat memenuhi kebutuhan nutrisi untuk meningkatkan pertumbuhan mikroba (Hapiza dkk., 2014).

Air kelapa adalah salah satu bahan alami, di dalamnya terkandung hormon seperti sitokinin 5,8 $\mathrm{m} / \mathrm{l}$, auksin $0,07 \mathrm{ml} / \mathrm{l}$ dan giberelin serta senyawa lain yang dapat menstimulasi perkecambahan dan petumbuhan. Peranan sitokinin dalam pembelahan sel tergantung pada adanya fitohormon lain terutama auksin (Rahayu dan Martono, 2015).

Bahan yang digunakan pada penelitian ini yaitu limbah cair tempe dan air kelapa, plastik tahan panas, alkohol, kultur jamur Aspergillus sp. dalam bentuk granul yang diperoleh dari Laboratorium Bioteknologi Jurusan Biologi FMIPA Universitas Tadulako.

10\%), P5 (aplikasi biofertilzer 12,5\%), P6 (aplikasi NPK, tanpa aplikasi biofertilizer sebagai kontrol positif).

Keterangan :

Biofertlizer : berbahan aktif Aspergillus sp. Bentuk sediaan cair, formula media pembawa terdiri dari limbah cair industri tempe dan air kelapa.

\section{Pelaksanaan Penelitian}


1. Penyediaan Jamur Aspergillus sp.

Jamur Aspergillus sp. Dalam bentuk sediaan granul sebanyak $50 \mathrm{~g}$ yang berasal dari koleksi laboratorium Jurusan Biologi Laboratorium Bioteknologi FMIPA UNTAD.

\section{Pembuatan Media Formula}

Formula media terdiri dari limbah cair tempe 2,5 L dan air kelapa 2,5 L. Kedua bahan tersebut dicampur kemudian disterilkan dengan menggunakan autoclave, suhu $121^{\circ} \mathrm{C}$ selama 15 menit. Aspergillus sp. sediaan granul sebanyak $50 \mathrm{~g}$ diinokulasikan ke dalam medium formula, selanjutnya ditutup dalam kondisi terhubung dengan aerator untuk mendapatkan eaerasi.

\section{Tahap Penyiapan Media Tanam}

Media yang akan digunakan untuk menanam bayam adalah tanah dengan campuran sekam padi dan abu yang dimasukkan kedalam pollybag berukuran $25 \times 30 \mathrm{~cm}$.

\section{Penanaman}

Benih bayam yang akan ditanam direndam terlebih dahulu selama 2 jam guna mempercepat pemecahan dormansi benih (Sidemen dkk., 2017). Benih yang ditanam sebanyak 3 biji perpot,.

\section{Aplikasi Pupuk Biofertilizer}

Biofertilizer sediaan cair diaplikasikan sebanyak 2 kali yaitu pada minggu pertama dan minggu ketiga setelah tanam sebanyak $500 \mathrm{~mL}$ dengan cara menyiramkan langsung ketanaman bayam, sesuai perlakuan dalam racangan penelitian.

\section{Pemeliharaan}

Penyiraman dilakukan secara rutin sekali dalam sehari yaitu pada sore hari dan penyiangan gulma dilakukan untuk mencegah terjadinya kompetisi unsur hara antara tanaman dengan gulma (Sidemen dkk., 2017).

\section{Pemanenan}

Pemanenan bayam dilakukan saat umur tanaman bayam 20 hari setelah tanam, dengan cara menyiram akar tanaman hingga terlepas dari tanah.

\section{Pengamatan Penelitian}

\section{a. Tinggi Tanaman (cm)}

Pengukuran dimulai saat tanaman berumur 5 hari sampai berumur 20 hari setelah tanam. Pengukuran dilakukan dari batas akar sampai bagian tanaman tertinggi.

\section{b. Jumlah Daun (helai)}

Penghitungan terhadap jumlah daun dilakukan setiap 5 hari sekali. Daun yang dihitung adalah daun yang telah terbentuk sempurna.

\section{c. Biomassa (g)}

Pengamatan biomassa tanaman dilakukan setelah selesai panen dengan cara menimbang seluruh bagian tanaman. 


\section{d. Berat Segar Tajuk (g)}

Pengamatan berat segar tajuk dilakukan setelah selesai panen dengan cara menimbang tanaman bagian tajuk tanpa akar.

\section{e. Berat Segar dan Kering Daun (g)}

Pengamatan berat segar daun dilakukan dengan cara menimbang daun yang masih segar. Berat kering daun dilakukan dengan cara terlebih dahulu mengeringkan daun dalam oven suhu $80^{\circ} \mathrm{C}$ selama 48 jam, kemudian ditimbang.

\section{f. Berat Segar dan Kering Akar}

Pengamatan berat segar akar dilakukan dengan cara menimbang akar yang masih segar. Berat kering

\section{HASIL DAN PEMBAHASAN}

\section{Tinggi Tanaman (cm)}

Hasil pengamatan menunjukkan bahwa pemberian biofertilizer berpengaruh nyata terhadap tinggi tanaman bayam merah (A. tricolor L.). Data rata-rata tinggi tanaman dengan perlakuan yang berbeda dapat dilihat pada Gambar 1.

Nilai rata-rata tinggi tanaman bayam merah ( $A$. tricolor L.) tertinggi pada perlakuan P4 $(10 \mathrm{~cm})$, disusul P1 $(9,05$ $\mathrm{cm})$, P0 $(8,82 \mathrm{~cm})$, P2 $(7,97 \mathrm{~cm})$, P5 $(7,02 \mathrm{~cm})$, P3 $(6,80 \mathrm{~cm})$ dan terendah pada perlakuan P6 $(5,92 \mathrm{~cm})$. akar dilakukan dengan cara terlebih dahulu mengeringkan akar dalam oven suhu $80^{\circ} \mathrm{C}$ selama 48 jam, kemudian ditimbang..

\section{g. Panjang Akar (cm)}

Akar diukur dengan cara membentangkan mulai pangkal sampai ujung, kemudian diukur panjangnya.

\section{Analisis Data}

Data-data yang diperoleh dari hasil pengamatan dilakukan analisis sidik ragam "one way anova". Bilamana terjadi perbedaan terhadap masing-masing perlakuan dilakukan uji lanjut Duncan pada taraf $5 \%$.

Pengamatan tinggi tanaman bertujuan untuk melihat adanya pertambahan ukuran tinggi pada tanaman. Hasil pengamatan yang dilakukan bahwa pemberian biofertilizer berbahan dasar limbah cair tempe dan air kelapa dengan pemberian mikroorganisme (Aspergillus sp.) sangat berpengaruh terhadap pertambahan tinggi tanaman. Nilai ratarata tanaman bayam tertinggi yaitu pada perlakuan P4 $(10 \mathrm{~cm})$ dan terendah pada perlakuan P6 (5,92 cm). Jamur Aspergillus sp. berpotensi sangat baik dalam mendukung pertumbuhan tinggi tanaman. Menurut penelitian Sihite (2011), jamur Aspergillus sp. berkemampuan tinggi dalam melarutkan 
unsur fosfor, sehingga tanaman dapat menyerap ion fosfat dalam bentuk ion $\mathrm{H}_{2} \mathrm{PO}_{4}$. Unsur fosfor tersebut dibutuhkan tanaman sebagai proses metabolisme untuk merangsang pertumbuhan tanaman, perkembangan akar, pertumbuhan buah, mendukung pembelahan sel dan memperkuat batang.

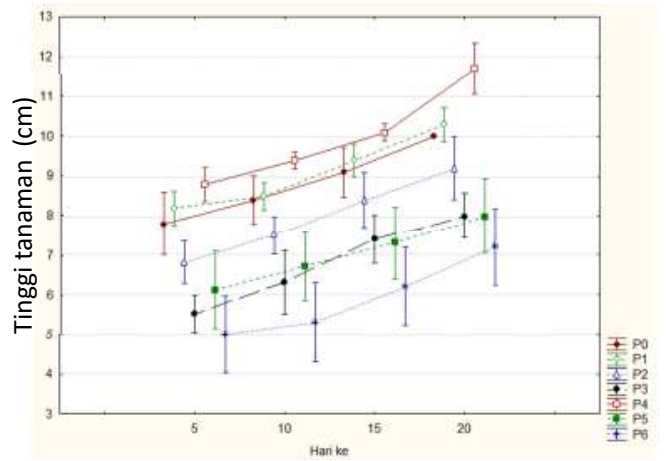

Gambar 1 Rata-rata tinggi tanaman (cm)

\section{Jumlah Daun (helai)}

Hasil pengamatan dan analisis ragam menunjukkan bahwa pemberian biofertilizer berpengaruh nyata pada jumlah daun bayam merah ( $A$. tricolor L.). Data rata-rata jumlah daun dengan perlakuan yang berbeda dapat dilihat pada Gambar 2.

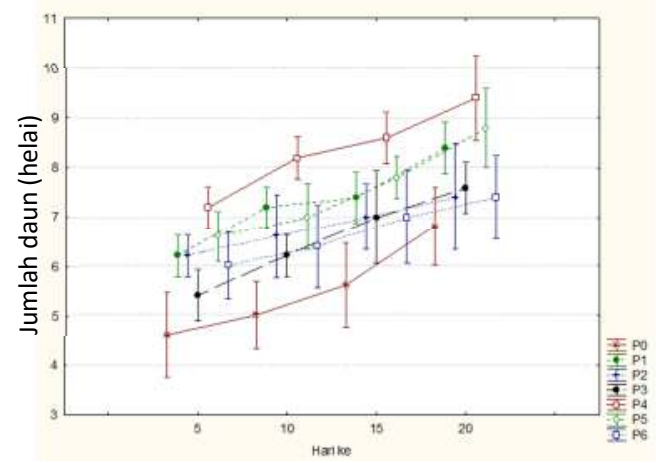

Gambar 2 Rata-rata jumlah daun (helai)
Nilai rata-rata jumlah daun tanaman bayam merah (A. tricolor L.) tertinggi pada perlakuan $\mathrm{P} 4$ (8,35 helai) disusul perlakuan P5 (7,55 helai), P1 $(7,30$ helai), P2 (6,80 helai), P6 (6,70 helai), P3 (6,55 helai) dan terendah pada perlakuan P0 (5,50 helai).

Pengamatan terhadap jumlah daun menunjukkan bahwa pengaplikasian biofertilizer dengan bahan dasar limbah cair tempe dan air kelapa dan tambahan mikroorganisme berupa jamur Aspergillus sp. dapat meningkatkan jumlah daun. Jumlah daun tertinggi berada pada perlakuan P4 (8,35 helai) dan rata-rata nilai terendah pada perlakuan P0 (5,50 helai). Unsur N sangat penting untuk proses fotosintesis, apabila penyerapan $\mathrm{N}$ terhambat, maka akan berpengaruh terhadap kerja fotosintesis sehingga berpengaruh terhadap jumlah daun, tanaman mempunyai batas zona kecukupan penyerapan unsur hara, apabila berlebihan maka akan menyebabkan keracunan bagi tanaman (Wakerkwa dkk, 2017).

\section{Biomassa (g)}

Hasil pengamatan berat biomassa tanaman bayam merah (A. tricolor L.) berbeda nyata pada setiap perlakuan, nilai rata-rata tertinggi pada perlakuan $\mathrm{P} 4$ (1,95 g), disusul perlakuan P1 (0,92 g), P0 (0,80 g), P5 (0,70 g), P6 (0,50 g), P2 
$(0,40 \mathrm{~g})$, dan nilai rata-rata terendah pada perlakuan P3 $(0,30 \mathrm{~g})$.

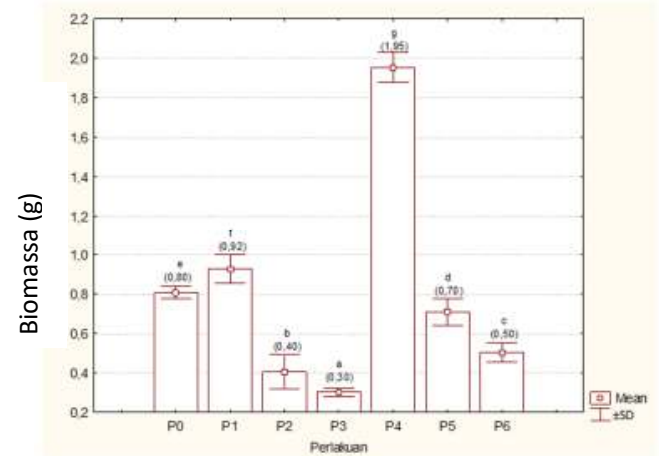

Gambar 3 Biomassa (g)

Pengamatan terhadap biomassa tanaman bayam (A. tricolor L.) menunjukkan bahwa pengaplikasian biofertilizer memberikan pengaruh nyata terhadap pertumbuhan tanaman bayam. Nilai rata-rata tertinggi pada perlakuan P4 (1,95 g). Biofertilizer diaplikasikan melalui daun yang mengandung unsur hara makro dan mikroesensial $(\mathrm{N}, \mathrm{P}, \mathrm{K}$, $\mathrm{S}, \mathrm{Ca}, \mathrm{Mg}, \mathrm{B}, \mathrm{Mo}, \mathrm{Cu}, \mathrm{Fe}, \mathrm{Mn}$, dan bahan organik). Manfaat biofertilizer diantaranya dapat mendorong dan meningkatkan pembentukan klorofil daun dan pembentukan bintil akar pada tanaman sehingga meningkatkan kemampuan fotosintesis tanaman dan penyerapan nitrogen dari udara (Rizqiani dkk., 2007).

Biomassa tanaman sangat erat kaitannya dengan organ yang ada pada tanaman yaitu daun, pada daun terjadi proses fotosintesis, hasil fotosintesis kemudian terakumulasi menjadi berat kering tanaman bayam tersebut. Pertumbuhan daun yang semakin baik maka semakin besar pula berat kering tanaman tersebut. Bila tanaman mendapatkan unsur $\mathrm{N}$ yang cukup maka daun akan tumbuh besar dan memperluas permukaannya. Permukaan daun yang luas tersebut dapat memungkinkan cahaya matahari diserap lebih banyak sehingga proses fotosintesis berlangsung lebih cepat sehingga fotosintat yang terbentuk akan terakumulasi pada bobot kering tanaman (Amir dkk., 2012).

\section{Berat Segar Tajuk (g)}

Hasil pengamatan berat segar tajuk tanaman bayam merah (A. tricolor L.) berbeda nyata pada setiap perlakuan, nilai rata-rata tertinggi pada perlakuan $\mathrm{P} 4$ $(4,94 \mathrm{~g})$ disusul perlakuan P5 (2,85 g), P1 (2,83 g), P0 (2,70 g), P3 (2,67 g), P2 $(2,42 \mathrm{~g})$ dan nilai rata-rata terendah pada perlakuan P6 (2,37 g).

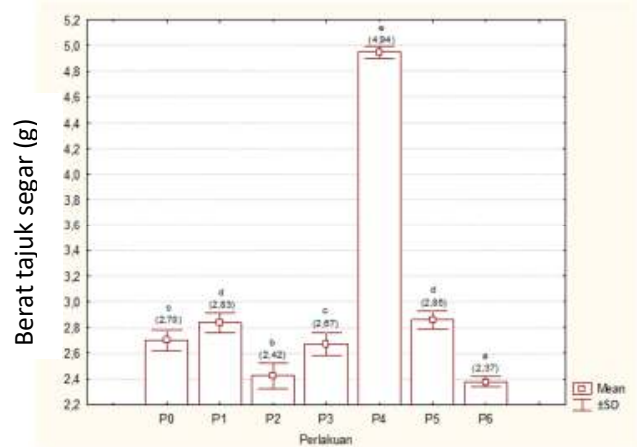

Gambar 4 Berat Segar Tajuk (g) 
Pengamatan terhadap berat segar tajuk tanaman bayam (A. tricolor L.) dengan pengaplikasian biofertilizer memberikan pengaruh nyata bagi tanaman. Semakin tinggi konsentrasi biofertilizer yang diberikan maka semakin banyak unsur $\mathrm{N}$ yang diserap oleh tanaman bayam untuk pertumbuhan. Nilai rata-rata tertinggi pada perlakuan P4 (4,94 g).

Bobot segar tanaman sangat dipengaruhi oleh tersedianya unsur hara dalam tanah dan keseimbangan hara tanah dapat mempengaruhi hasil. Pemberian bahan organik yang mengandung nitrogen akan meningkatkan bobot segar tanaman sayuran. Hubungan yang sangat nyata antara tinggi tanaman, jumlah daun dan luas daun, dengan demikian maka peningkatan komponen-komponen tersebut akan meningkatkan berat segar tajuk tanaman (Lehar, 2010).

\section{Berat Segar dan Kering Daun (g)}

Hasil pengamatan berat segar daun bayam merah ( $A$. tricolor L.) berbeda nyata pada setiap perlakuan, nilai ratarata tertinggi pada perlakuan P4 $(2,07 \mathrm{~g})$ disusul perlakuan P5 (1,08 g), P2 (1,06 g), P6 (1,06 g), P3 (1,04 g), P1 (1,03 g) dan rata-rata nilai terendah pada perlakuan P0 $(1,02 \mathrm{~g})$ dapat dilihat pada Gambar 5.

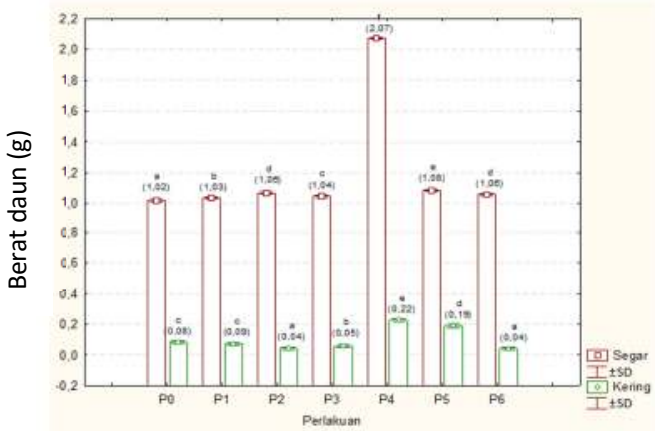

Gambar 5 Berat segar dan kering daun (g)

Hasil pengamatan berat kering daun bayam ( $A$. tricolor L.) berbeda nyata pada setiap perlakuan, nilai rata-rata tertinggi pada perlakuan P4 $(0,22 \mathrm{~g})$ disusul perlakuan P5 (0,19 g), P1 (0,09 g), P0 (0,08 g), P3 (0,05 g) rata-rata nilai terendah pada perlakuan P2 $(0,04 \mathrm{~g})$ dan P6 $(0,04 \mathrm{~g})$ dapat dilihat pada Gambar 5 . Pengamatan terhadap berat segar dan kering daun tanaman bayam ( $A$. tricolor L.) dengan pengaplikasian biofertilizer memberikan pengaruh nyata bagi tanaman, nilai rata-rata tertinggi berat segar daun pada perlakuan P4 (2,07 g) dan berat kering daun pada perlakuan P4 (0,22 g). Besarnya berat basah dan berat kering daun tanaman bayam pada perlakuan P4 berhubungan dengan penyerapan unsur hara makro $\mathrm{N}, \mathrm{P}$ dan $\mathrm{K}$ seperti yang diketahui bahwa unsur $\mathrm{N}$ berperan penting dalam pembentukan klorofil sehingga proses fotosintesis tanaman semakin baik.

Semakin baiknya proses fotosintesis 
maka akan mendukung pertumbuhan vegetatif tanaman semakin baik pula. Semakin meningkatnya laju fotosintesis dan penumpukan asimilat akan semakin meningkatnya berat kering tanaman yang hampir $90 \%$ berat kering merupakan hasil fotosintesis (Nirmalayanti dkk., 2017).

\section{Berat Segar dan Kering Akar (g)}

Hasil pengamatan berat segar akar bayam ( $A$. tricolor L.) berbeda nyata pada setiap perlakuan, nilai rata-rata tertinggi pada perlakuan P4 $(2,11 \mathrm{~g})$ disusul perlakuan P0 (1,09 g), P6 (1,09 g), P5 (1,08 g), P2 (1,08 g), P1 (1,06 g) dan nilai rata-rata terendah pada perlakuan P3 $(1,04 \mathrm{~g})$ dapat dilihat pada Gambar 6.

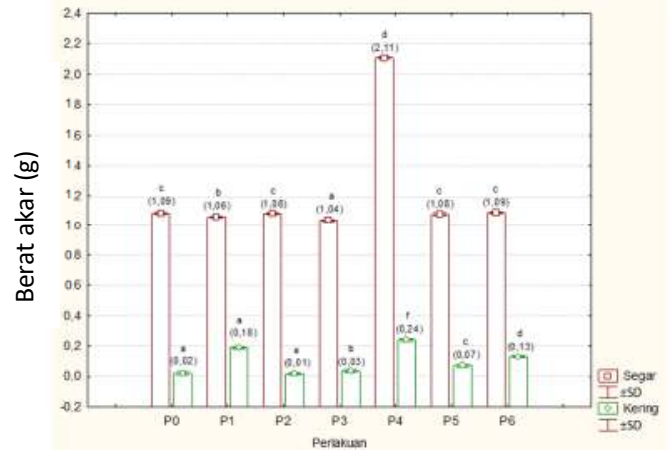

Gambar 6 Berat segar dan kering akar (g)

Hasil pengamatan berat kering akar bayam ( $A$. tricolor L.) berbeda nyata pada setiap perlakuan, nilai rata-rata tertinggi pada perlakuan P4 $(0,24 \mathrm{~g})$ disusul perlakuan P1 (0,18 g), P6 (0,13 g) P5 (0,07 g) P3 (0,03 g), P0 (0,02 g) dan rata-rata nilai terendah pada perlakuan P2 $(0,01 \mathrm{~g})$ dapat dilihat pada Gambar 6.

Pengamatan terhadap berat segar dan kering akar tanaman bayam (A. tricolor L.) dengan pengaplikasian biofertilizer berbahan dasar limbah cair tempe dan air kelapa dengan tambahan mikroorganisme (Aspergillus sp.) memberikan pengaruh nyata bagi tanaman, nilai rata-rata tertinggi berat segar akar pada perlakuan P4 (2,11 g) dan berat kering akar pada perlakuan P4 $(0,24 \mathrm{~g})$. Hal ini menunjukkan peran limbah cair industri tempe memiliki pengaruh yang sangat besar terhadap berat kering akar. Pada limbah cair industri tempe, unsur hara $\mathrm{N}$ cukup untuk proses pembelahan dan pemanjangan akar. Nitrogen yang cukup pada tanaman akan mempercepat laju pembelahan dan pemanjangan akar, batang dan daun. Unsur hara yang telah diserap akar memberi kontribusi terhadap penambahan berat kering tanaman (Hapiza dkk., 2014).

Proses pembuatan tempe termasuk dalam limbah bahan buangan yang dapat dihancurkan oleh mikroorganisme. Dari senyawa amonium dan nitrat yang dihasilkan dari limbah cair industri tempe, dapat dimanfaatkan akar tanaman sebagai nutrisi untuk pertumbuhan tanaman (Hapiza dkk., 2014). 


\section{Panjang Akar (cm)}

Hasil pengamatan panjang akar bayam (A. tricolor L.) berbeda nyata pada setiap perlakuan, nilai rata-rata tertinggi pada perlakuan P4 (12,2 cm) disusul perlakuan P5 $(10,9 \mathrm{~cm})$, P1 $(10,6 \mathrm{~cm})$, P3 $(9,1 \mathrm{~cm})$, P2 $(9 \mathrm{~cm})$, P6 $(8,9 \mathrm{~cm})$ dan rata-rata nilai terendah pada perlakuan PO $(6,8 \mathrm{~cm})$.

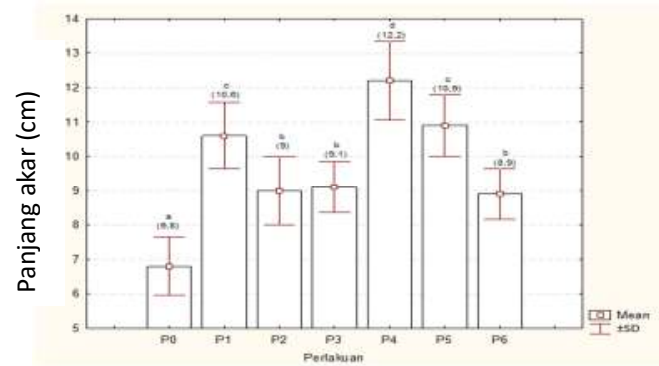

Gambar 7 Panjang akar (cm)

Pengamatan terhadap panjang akar tanaman bayam (A. tricolor L.) dengan pengaplikasian biofertilizer memberikan pengaruh nyata bagi tanaman, unsur $\mathrm{N}$ berfungsi dalam membantu pertumbuhan akar (Wakerkwa dkk., 2017). Nilai ratarata tertinggi pada perlakuan P4 (12,2 $\mathrm{cm})$. Nilai rata-rata terendah pada perlakuan P0 $(6,8 \mathrm{~cm})$. Kekurangan $\mathrm{N}$ dapat mempengaruhi pertumbuhan akar. Tingkat konsentrasi hara yang rendah, perakaran mengalami defisiensi unsur hara tertentu dan penghambatan distribusi hara. Hal inilah yang mengakibatkan kurangnya pertumbuhan akar. Jumlah oksigen terlarut dalam air juga mempengaruhi pertumbuhan tanaman (Wakerkwa dkk., 2017).

\section{SIMPULAN}

Biofertilizer (Bahan aktif Aspergillus sp.) berbahan dasar limbah cair tempe dan air kelapa dapat diterapkan pada pertumbuhan tanaman bayam (A. tricolor L.). Pada perlakuan P4 (aplikasi biofertilizer 10\%) menunjukkan pertumbuhan yang baik bagi tanaman bayam ( $A$. tricolor L.) untuk tinggi tanaman $(10 \mathrm{~cm})$, jumlah daun $(8,35$ helaian), berat biomassa $(1,95 \mathrm{~g})$, berat tajuk segar $(4,94 \mathrm{~g})$, berat segar daun $(2,07$ $\mathrm{g})$, berat kering daun $(0,22 \mathrm{~g})$, berat segar akar $(2,11 \mathrm{~g})$, berat kering akar $(0,24 \mathrm{~g})$ dan panjang akar $(12,2 \mathrm{~cm})$.

\section{DAFTAR PUSTAKA}

Amir, L., Sari, A. P., Hiola, S. F., dan Jumadi, O. 2012. Ketersediaan nitrogen tanah dan pertumbuhan tanaman bayam (Amaranthus tricolor L.) yang diperlakukan dengan pemberian pupuk kompos azolla. Sainsmart, I(2), 167-180.

Biswas B.C. Yadav D.S. and Satish Maheshwari. 1985. Biofertilizers in Indian Agriculture. Ferttilizer News 30 (10); 20-28.

Duaja, W. 2012. Pengaruh Pupuk Urea, Pupuk Organik Padat dan Cair Kotoran Ayam Terhadap Sifat Tanah, Pertumbuhan dan Hasil Selada Keriting di Tanah Inceptisol, 1(4), 236246.

Hapiza, M. R., Sabrina, T., dan Marbun, P. 2014. PengaruhPemberian Limbah 
Cair Industri Tempe dan Mikoriza Terhadap Ketersediaan Hara N dan $\mathrm{P}$ Serta Produksi Jagung (Zea mays L.) Pada Tanah Inceptisol. Online Agroekologi, 2(2337), 1098-1106.

Jawetz, E., Melnick and Adelberg, 1996, Mikrobiologi kedokteran, edisi 20, Halaman 631-632, EGC, Jakarta

Kagot, V., Okoth, S., Boevre, M. De, and Saeger, S. De. (2019). Biocontrol of Aspergillus and Fusarium mycotoxins in Africa: benefits and limitations. Journal Of Toxins, 109(11), 1-9.

Kuhn, O.J. 2007. Induction of resistance in common bean (Phaseolus vulgaris) by Acbenzolars-methyl and Bacillus cereus: physiological and biochemical aspects and parameters of growth and production. PhD. Thesis, Higher School of Agriculture Luiz de Queiroz. Universidade de Sao Paulo, Brazil.

Lehar, L. 2010. Pertumbuhan dan hasil bayam (Amaranthus cruentus L.) akibat pemanfaatan bahan organik cair hasil fermentasi isi rumen. Penelitian Pertanian Terapan, 10(3), 164-170.

Nirmalayanti, K. A., Subadiyasa, I. N. N., dan Arthagama, I. D. M. 2017. Peningkatan produksi dan mutu tanaman bayam merah (Amaranthus amoena Voss.) melalui beberapa jenis pupuk pada tanah inceptisols, Desa Pegok, Denpasar. E-Jurnal Agroteknologi Tropika, 6(1), 1-10.

Rahayu, S., dan Martono, D. S. 2015. Uji Perkembangbiakan Miselia Bibit Jamur
Tiram Putih (Pleurotus ostreatus) Dengan Substrat Campuran Air Kelapa Dan Air Leri. Jurnal Agritek, 16(2), 4760.

Rizqiani, N. F., Ambarwati, E., dan Yuwono, N. W. 2007. The Effect of Dosage and Frequence of Liquid Organic Fertilizer on Growth and Yield of Lowland Beans (Phaseolus Vulgaris L.). Jurnal IImu Tanah Dan Lingkungan, 7(1), 43-53.

Sidemen, I. N., Raka, I. D. N., dan Udiyana, P. B. 2017. Pengaruh Jenis Pupuk Organik Terhadap Pertumbuhan Tanaman Bayam (Amaranthus sp.) Pada Tanah Tegalan Daerah Kubu, Karangasem. Jurnal Agrimeta, 7(13), 31-40.

Silva, D. M., Batista, L. R., Rezende, E. F., Fungaro, M. H. P., Sartori, D., and Alves, E. 2011. Identification of fungi of the genus Aspergillus section Nigri using polyphasic taxonomy. Brazilian Journal Of Microbiology, 42, 761-773.

Varga, J., Kocsube, S., Toth, B., Frisvad, J. C., Perrone, G., Susca, A., Samson, R. A. 2019. Aspergillus brasiliensis sp. nov., a biseriate black Aspergillus species with world-wide distribution. International Journal Of Systematic and Evolutionary Microbiology, (2007),

Wakerkwa, R., Tilaar, W., dan PoliiMandang, J. S. 2017. Aplikasi Pupuk Cair Terhadap Pertumbuhan dan Produksi Tanaman Bayam Merah (Amaranthus sp). Agri-SosioEkonomi Unsrat, 13(November), 283-294. 